\title{
Failure of a Pure Progestogen Contraceptive to Affect Serum Levels of Iron, Transferrin, Protein-bound Iodine, and Transaminase
}

\author{
L. W. POWELL,* M.D., M.R.A.C.P. ; J. M. JACOBI,† B.SC. ; T. J. GAFFNEY, † M.B., B.S., PH.D. ; R. ADAM,† M.B., B.S.
}

\begin{abstract}
Cummary: Medroxyprogesterone acetate, a pure $\checkmark$ progestational agent which is not metabolized to oestrogen, was given to 30 women and shown to have no effect on the serum levels of iron, total iron-binding capacity, transferrin, and protein-bound iodine. Eighteen of these women had previously taken oral contraceptives of the combined oestrogen-progestogen "sequential" type, and during that time these serum levels were raised. Nevertheless, the levels all fell significantly after medroxyprogesterone acetate was given and the "sequential" oral contraceptive was stopped. In a further 12 postpartum women the serum levels did not change significantly after medroxyprogesterone acetate.
\end{abstract}

These observations strongly suggest that raised plasma protein levels resulting from the administration of oral contraceptives are due to the oestrogen component.

\section{Introduction}

The serum levels of iron, total iron-binding capacity (T.I.B.C.), transferrin, and protein-bound iodine (P.B.I.), as well as other proteins, are significantly raised during pregnancy and the administration of oral contraceptives (Burton, 1967; Zadeh et al., 1967; Jacobi et al., 1969; Horne et al., 1970). It is uncertain, however, whether these changes are due to the increased serum levels of oestrogens, progestogens, or both (British Medical fournal, 1970; Lancet, 1970) though there is increasing evidence to implicate the oestrogen component (Hollander et al., 1963; Winikoff and Taylor 1966).

The purpose of the present study was to show whether a pure progestational agent, used as an ovulatory inhibitor, affects these serum protein levels in the same manner as oombined oestrogen-progestogen preparations.

\section{Subjects and Methods}

Four groups of women were investigated. Controls (group 1) were healthy nulliparous women (mean age 23 years, range 17-30) without evidence of anaemia, pathological blood loss, or history of blood donations during the previous six months. Groups 2, 3, and 4 attended a family-planning clinic. Women in group 2 were using "sequential" type oral contraceptives at the time of study (Table I). Women in group 3 had taken "sequential" type oral contraceptives for three to six months, and immediately after stopping the drug received a single

TABLE I.-Composition of the "Sequential" Type Oral Contraceptives used by Women in Group 2

\begin{tabular}{|c|c|c|c|c|c|c|}
\hline \multicolumn{4}{|c|}{ Trade Name } & \multirow{2}{*}{\begin{tabular}{|c|c}
$\begin{array}{c}\text { Dosage } \\
\text { Began Day } 5\end{array}$ \\
7 tablets \\
7 tablets \\
7 tablets
\end{tabular}} & \multirow{2}{*}{$\begin{array}{c}\begin{array}{c}\text { Mestranol } \\
\text { Content }\end{array} \\
\begin{array}{l}0.1 \mathrm{mg} . \\
0.1 \mathrm{mg} . \\
0.1 \mathrm{mg} .\end{array}\end{array}$} & $\begin{array}{c}\text { Anagestone } \\
\text { Content }\end{array}$ \\
\hline Neonovum & .. & . & .. & & & $\begin{array}{l}0.1 \overline{25} \mathrm{mg} . \\
0.25 \mathrm{mg} .\end{array}$ \\
\hline ORF 1658 & . & . & . & $\begin{array}{l}7 \text { tablets } \\
7 \text { tablets } \\
7 \text { tablets }\end{array}$ & $\begin{array}{l}0.1 \mathrm{mg} \text {. } \\
0.1 \mathrm{mg} \text {. } \\
0.1 \mathrm{mg} .\end{array}$ & $\begin{array}{ll}1.0 & \\
2.0 & \mathrm{mg} . \\
\mathrm{mg} .\end{array}$ \\
\hline SQI III & . & .. & .. & $\begin{array}{l}7 \text { tablets } \\
7 \text { tablets } \\
7 \text { tablets }\end{array}$ & $\begin{array}{l}0.1 \mathrm{mg} . \\
0.1 \mathrm{mg} . \\
0.1 \mathrm{mg} .\end{array}$ & $\begin{array}{l}0.25 \mathrm{mg} . \\
0.5 \mathrm{mg} .\end{array}$ \\
\hline
\end{tabular}

*17-hydroxy-b $\alpha$-methylpregn-4-en-20-one acetate.

* Reader in Medicine.

†Research Assistant.

$¥$ Biochemist.

Departments of Medicine and Obstetrics, University of Queensland, and Department of Pathology, Royal Brisbane Hospital, Brisbane. intramuscular injection of $300 \mathrm{mg}$. of medroxyprogesterone acetate (Depo Provera) as a contraceptive agent lasting four to six months. Women in group 4 were four to six weeks postpartum and received Depo Provera as above without previous oral contraceptive therapy.

Blood was collected without venous occlusion and the serum stored at $-20^{\circ} \mathrm{C}$. until tested. The serum levels of iron, T.I.B.C., transferrin, P.B.I., and aspartate aminotransferase (S.G.O.T.) were measured quantitatively as previously described (Jacobi et al. 1969), the transferrin estimation being performed by the immunoprecipitation method of Ritchie (1967). In addition, the red cell haemoglobin concentration, packed cell volume (P.C.V.), and mean corpuscular haemoglobin concentration (M.C.H.C.) were measured in each subject by standard methods (Strumia et al., 1954; King and Woctton, 1956).

\section{Results}

The values obtained in the control group are shown in Table II. As reported previously (Jacobi et al., 1969) the serum iron, T.I.B.C., transferrin, and P.B.I. levels were all strikingly raised in women taking combined oestrogen-progestogen oral contraceptives but there was no significant rise in S.G.O.T. concentration (Table III). In this group the haemoglobin concentration and M.C.H.C. were also significantly raised while the P.C.V. remained unaffected. The serum levels in women taking a "sequential" type oral contraceptive preparation (group 3) were raised similarly to those of group 2, but fell significantly after this drug was stopped and $300 \mathrm{mg}$. of medroxyprogesterone given by injection (Fig. 1). All but the serum transferrin levels were then within the normal range. The haemoglobin, P.C.V., and M.C.H.C. levels did not alter significantly compared with baseline (pre-injection) values over this period (mean values respectively three months after the Depo Provera injection were $14.1 \pm 0.9 \mathrm{~g} . / 100 \mathrm{ml}$., $42 \pm 2.6 \%$, and $33 \pm 2.1 \%)$. The values for S.G.O.T. in this group were normal throughout the study. In the postnatal group (Fig. 2) all levels studied were again uninfluenced by the progestogen administration.

\section{Discussion}

The results of this study strongly suggest that alterations in plasma protein levels in pregnancy and during the administration of oral contraceptives are due to oestrogens. The increased serum levels of iron, T.I.B.C., transferrin, and P.B.I. in women who had been taking combined oestrogenprogestogen oral contraceptives fell significantly to normal or near normal levels after these drugs were stopped and a pure progestational agent was given (Fig. 1). Further, the levels of these serum proteins in postnatal women did not change significantly during three months' observation after the progestogen administration (Fig. 2). Rises in plasma protein levels can be produced by the oestrogen alone (Seal and Doe, 1969). Though it has been claimed that progesterone therapy influences the serum T.I.B.C. levels (Musa et al., 1967; Briggs and Staniford, 1969), we are unaware of any confirmation of this when using a pure progestational drug such as medroxyprogesterone acetate which is not metabolized to oestrogen (Carey, 1963).

There have been conflicting reports of the effects of oral contraceptives on hepatic function. Adlercreutz et al., (1968) 
TABLE II-Results in Control Subjects (Group 1) (Mean Values \pm S.D.)

\begin{tabular}{|c|c|c|c|c|c|c|c|}
\hline $\begin{array}{c}\text { Red Cell } \\
\text { Haemoglobin } \\
\text { Concentration } \\
(\mathrm{g} .1100 \text { ml. })\end{array}$ & $\begin{array}{l}\text { P.C.V. } \\
(\%)\end{array}$ & $\underset{(\%)}{\text { M.C.H.C. }}$ & $\begin{array}{l}\text { Serum Iron } \\
(\mu \mathrm{g} . / 100 \mathrm{ml} .)\end{array}$ & $\begin{array}{l}\text { T.I.B.C. } \\
(\mu \mathrm{g} . / 100 \mathrm{ml} .)\end{array}$ & $\begin{array}{c}\text { Serum Transferrin } \\
\left(\mu_{\mathrm{g} .} / 100 \mathrm{ml} .\right)\end{array}$ & $\underset{(\mu \mathrm{g} . / 100 \mathrm{ml} .)}{\text { P.B.I. }}$ & $\begin{array}{l}\text { S.G.O.T. (Karmen } \\
\text { Units/ioo ml.) }\end{array}$ \\
\hline $12.7 \pm 0.7(10)$ & $40 \pm 0 \cdot 8(10)$ & $31 \pm 2 \cdot 0(10)$ & $102 \pm 38 \cdot 1$ & $387 \pm 49 \cdot 4$ & $279 \pm 58 \cdot 5$ & $5 \cdot 9 \pm 1 \cdot 1(16)$ & $11.2 \pm 6.3(12)$ \\
\hline
\end{tabular}

The numbers in parentheses indicate total number of subjects tested.

TABLE III.-Results in Women Taking Sequential Type Oral Contraceptives (Group 2)

\begin{tabular}{|c|c|c|c|c|c|c|c|c|}
\hline & $\begin{array}{c}\text { Red Cell } \\
\text { Haemoglobin } \\
\text { Concentration } \\
(\mathbf{g} . / 100 \mathrm{ml} .)\end{array}$ & $\begin{array}{l}\text { P.C.V. } \\
(\%)\end{array}$ & $\underset{(\%)}{\text { M.C.H.C. }}$ & $\begin{array}{c}\text { Serum Iron } \\
(\mu \mathrm{g} . / 100 \mathrm{ml} .)\end{array}$ & $\begin{array}{c}\text { T.I.B.C. } \\
(\mu \mathrm{g} . / 100 \mathrm{ml} .)\end{array}$ & $\begin{array}{c}\text { Serum } \\
\text { Transferrin } \\
(\mu \mathrm{g} . / 100 \mathrm{ml} .)\end{array}$ & $\begin{array}{l}\text { P.B.I. } \\
(\mu \mathrm{g} . / 100 \mathrm{ml} .)\end{array}$ & $\begin{array}{l}\text { S.G.O.T. (Karmen } \\
\text { Units/100 ml.) }\end{array}$ \\
\hline $\begin{array}{lll}\text { Mean } & . & \ldots \\
\text { S.D. } & \text {. } & \\
\text { No. of subjects } . \\
\text { P }\end{array}$ & $\begin{array}{l}13.7 \\
0.46 \\
12 \\
<0.01\end{array}$ & $\begin{array}{l}40 \\
1 \cdot 88 \\
12 \\
\text { N.S. }\end{array}$ & $\begin{array}{l}34 \\
1 \cdot 18 \\
12 \\
<0.01\end{array}$ & $\begin{array}{l}133 \\
37.43 \\
11 \\
<0.05\end{array}$ & $\begin{array}{l}554 \\
89.87 \\
11 \\
<0.001\end{array}$ & $\begin{array}{l}455 \\
98.89 \\
13 \\
<0.001\end{array}$ & $\begin{array}{l}8 \cdot 3 \\
1 \cdot 31 \\
13 \\
<0.001\end{array}$ & $\begin{array}{l}10 \cdot 7 \\
2 \cdot 63 \\
11 \\
\text { N.S. }\end{array}$ \\
\hline
\end{tabular}

$\mathbf{P}=\mathbf{P v}$. Control subjects (Students $t$ test.)

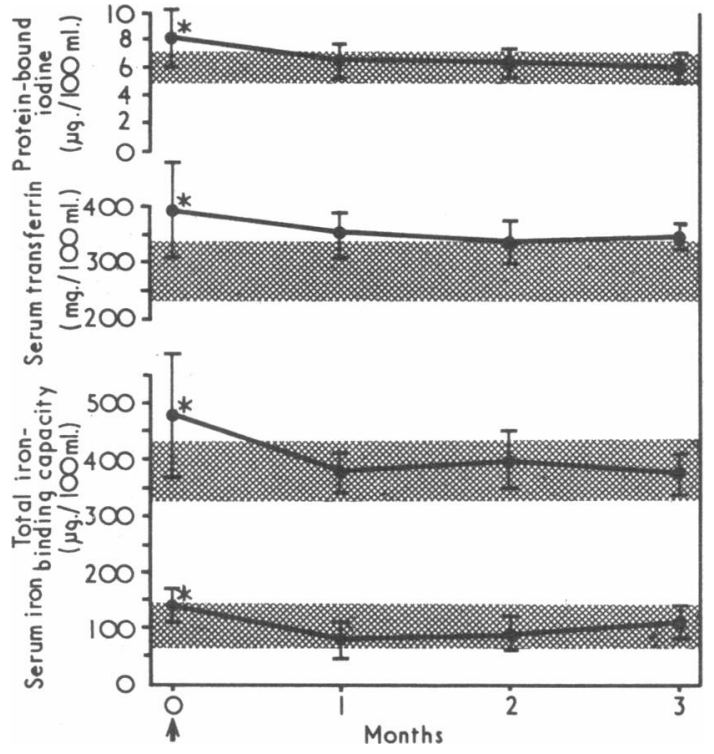

Fig. 1.-Serum levels in 18 women in group 3 (means \pm S.D.). At the point marked by the arrow oral contraceptives were stopped and the subjects received a single intramuscular injection of $300 \mathrm{mg}$. of medroxyprogesterone acetate. The values indicated by the asterisks are signifi-
cantly raised above the others. Shaded areas indicate normal means \pm 1 S.D.

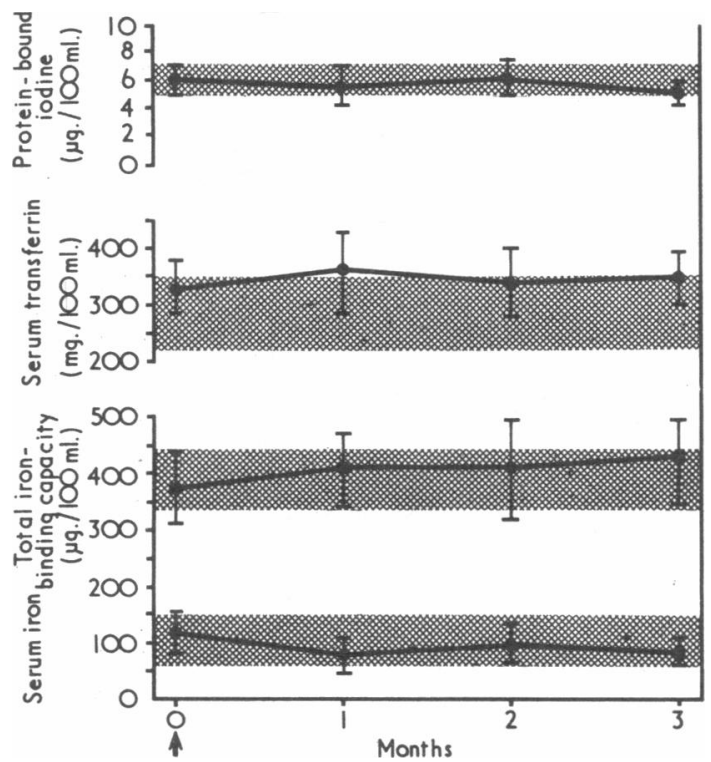

FIG. 2.-Serum levels in 12 post-partum women who received $300 \mathrm{mg}$. of medroxyprogesterone acetate intramuscularly at the point indicated by the arrow. None of the levels rose significantly after the injection. the arrow. None of the levels rose significantly after the
Shaded areas indicate normal means \pm 1 S.D. and Mulligan and Sherlock (1968) found increased serum transaminase levels after administration of both oestrogen and progestogen. In contrast, Wilbert et al. (1969) found unchanged S.G.O.T. and serum alkaline phosphatase levels after oral contraceptive therapy, though raised levels of leucine aminopeptidase and delayed bromsulphthalein excretion occurred. We have found consistently normal levels of S.G.O.T. after combined oestrogen-progestogen oral contraceptive and parenteral progestogen administration.

The haematological findings reported in women taking oral contraceptives have also varied greatly. Burton (1967), for example, obtained raised values for P.C.V. but not for haemoglobin concentration or M.C.H.C. levels. Zadeh et al. (1967) found increased haemoglobin and P.C.V. levels in women taking "combined" oral contraceptives, and concluded that the increases were dependent on the type of progesterone component-methysterone acetate, showing most effect. The significantly raised levels for haemoglobin concentration and M.C.H.C. in women using either "sequential" type oral contraceptives or medroxyprogesterone acetate in our study might have resulted from diminished menstrual blood loss and, in group 4, from regular prophylactic oral iron therapy during pregnancy.

We are grateful to Dr. W. Inglis and Searle (Australasia) Pty. Ltd. for financial support and to Upjohn Pty. Ltd. for supplies of Depo Provera.

Requests for reprints should be addressed to $\mathrm{L}$. W. Powell, Department of Medicine, Royal Brisbane Hospital, Herston Road, Brisbane, Queensland, 4029, Australia.

\section{REFERENCES}

Adlercreutz, H., et al. (1968). Scandinavian fournal of Gastroenterology, 3, 273.

Briggs, M., and Staniford, M. (1969). Lancet, 2, 742.

British Medical fournal 1970, 1, 320.

Burton, J. L. (1967). Lancet, 1, 978.

Carey, H. M. (1963). In Modern Trends in Human Reproductive Physiology, ed. H. M. Carey, vol. 1, p. 101. London, Butterworth.

Hollander, C. S., Garcia, A. M., Sturgis, S. H., and Selenkow, H. A. (1963). New England fournal of Medicine, 269, 501.

Horne, C. H. W., Howie, P. W., Weir, R. J., and Goudie, R. B. (1970). Lancet, 1, 49.

Jacobi, J. M., Powell, L. W., and Gaffney, T. J. (1969). British Fournal of Haematology, 17, 503 .

King, E. J., and Wootton, I. D. P. (1956). Micro Analysis in Medical Biochemistry, 3rd edn., p. 225. London, Churchill.

Lancet, 1970, 1, 72.

Mulligan, R., and Sherlock, S. (1968). Clinical Trials fournal, 5, Special issue, p. 155 .

Musa, B. U., Doe, R. P. and Seal, U. S. (1967). Fournal of Clinical Endocrinology and Metabolism, 27, 1,463.

Ritchie, R. F. (1967). Fournal of Laboratory and Clinical Medicine, 70,

Seal, U. S., and Doe, R. P. (1969). In Metabolic Effects of Gonadal Hormones and Contraceptive Steroids, ed. H. A. Salhanick, D. M. Kipnis, and R. L. Vande Wiele, p. 277. New York, Plenum

Strumia, M. M., Sample. A. B., and Hart, E. D. (1954). American fournal of Clinical Pathology, 24, 1,016.

Wilbert, L., Severidt, E., Kallmann, L., Hillmer, T., and Creutzfeldt, W. (1969), German Medical Monthly, 14,451

Winikoff, D., and Taylor, K. (1966). Medical fournal of Australia, 2,

Zadeh, J. A., Karabus, C. D., and Fielding, J. (1967). Fournal of Clinical Pathology, 20, 918. 